ZOOLOGIA 32 (4): 306-316, August 2015

http://dx.doi.org/10.1590/S1984-46702015000400006

\title{
Taxonomic revision of two poorly known genera of Richardiidae (Diptera): Maerorichardia and Odontomerella
}

\author{
Lisiane Dilli Wendt ${ }^{1,2} \&$ Luciane Marinoni $^{1}$
}

\begin{abstract}
${ }^{1}$ Departamento de Zoologia, Universidade Federal do Paraná. Caixa Postal 19020, 81531-980 Curitiba, PR, Brazil.
${ }^{2}$ Corresponding author. E-mail: lisidilli@yahoo.com.br
\end{abstract}

\begin{abstract}
Richardiidae are a family of Tephritoidea in which most genera are poorly known taxonomically, including some which were poorly described with limited or no illustrations. With the aim to decrease this taxonomic gap, herein we review two scarcely known monotypic genera: Odontomerella Hendel, 1912 and Maerorichardia Hennig, 1937, both known only from the holotypes of their type species. Maerorichardia is the only genus of Richardiidae with mid and hind tibiae thicker than their respective femora, and the wing with the anal lobe distinctly developed. Odontomerella can be distinguished from the others richardiids by the postcranium reduced and little wider ventrally, the compound eye well developed, occupying most of the head, with the gena and postcranium very reduced, and the face short, with the oral margin distinctly concave. The limits of both genera are revised and better supported with the addition of new diagnostic characters. Odontomera flavipleura Hennig, 1938 is transferred to Odontomerella. The types of the species are revised and illustrated.
\end{abstract}

KEY WORDS. Neotropical Region; new combination; Richardiinae; terminalia.

Richardiidae are a small family of about 200 valid species (Steyskal 1968, Wendt \& Ale-Rocha 2014b, 2015) in 32 genera (Hancock 2010). The family only occurs in the New World, and the vast majority of species are recorded from the Neotropical Region (Aczél 1950, SteysKal 1968).

During the last five decades, richardiids were largely neglected and only a few sparse contributions were published during that period. Recently, however, the family has been the focus of more extensive taxonomic studies. Examples are an identification key to all genera (НАNCOCK 2010) and revisions of several genera (WendT \& Ale-Rocha 2012, 2014b), including new taxa (e.g. Perez-Gelabert \& Thompson 2006, Carvalho et al. 2011, Alencar et al. 2013, Wendt \& Ale-Rocha 2014a, b, 2015). Despite these efforts, however, many taxa still remain undescribed or scarcely studied.

Herein, we revise two poorly known genera: Odontomerella Hendel, 1912 and Maerorichardia Hennig, 1937. Both are monotypic, known only from their respective holotypes. HeNDEL (1912) described Odontomerella to accommodate Odontomerella oxyptera Hendel, 1912, based on a single male specimen. It has never been illustrated and recognition of this genus has remained uncertain. Maerorichardia was proposed by HeNNIG (1937) to include Maerorichardia lugubris Hennig, 1937, based on a single female specimen. This genus is recognized by the mid and hind tibiae being distinctly thickened (НАNCOCK 2010) and with a very characteristic wing: the alula and anal lobe are well developed. These diagnostic characters, as well as those for Odontomerella, have never been illustrated or described in detail. Herein, the limits of these genera are revised and better characterized with the addition of new diagnostic characters. The holotypes of these species are also redescribed and illustrated. Odontomera flavipleura Hennig, 1938 is transferred to Odontomerella and is redescribed and illustrated. Diagnosis and illustrations of head, wing, and male and female terminalia of Odontomera Macquart, 1843 are also provided to justify the transference of O. flavipleura to Odontomerella.

\section{MATERIAL AND METHODS}

The examined specimens were borrowed from the following collections, with the curators listed in parentheses: BMNH - Natural History Museum, London, England (K. Goodger); LACM - Natural History Museum of Los Angeles County, California, USA (B. Brown; originally, the material belonged to Utah State University, Entomological Museum, Logan, Utah, USA (EMUS), and it was loaned by W.J. Hanson, but recently the Diptera from this collection were transferred to LACM); MHNJP - Museo de História Natural Javier Prado, Universidad Nacional Mayor de San Marcos, Lima, Peru (G.L. Müller); SMTD - Senckenberg Natural History Collections, Dresden Museum of Zoology, Dresden, Germany (U. Kallweit); USNM - National Museum of Natural History, Washington, D.C., USA (A.L. Norrbom).

The external morphological terminology follows Cumming \& Wood (2009), whereas the female and male terminalia terminologies follow Norrboм \& Кім (1988) and Whiтe et 
al. (1999), respectively. Measurements of the head are presented as proportions, which were calculated always with the head in frontal view: 1) head width-height ratio: the greatest width of the head, including the eyes, divided by the greatest height of the head, measured from the vertex to the ventral limit of the face, without the clypeus; 2) frons-head ratio: the greatest width of the frons divided by the greatest width of the head; 3) frons width-height ratio: the greatest width of the frons divided by the greatest height of it, measured from the vertex to the dorsal margin of the lunule; 4) face-clypeus ratio: greatest height of the face, measured from the ventral margin of the scape insertion to the ventral limit of the face, divided by the greatest height of the clypeus; 5) ocelli-distance ratio: distance from the anterior ocellus to the posterior ocelli (drawing a continuous line on the ventral margin of the two ocelli) divided by the distance between the posterior ocelli.

The terminalia of the holotype of M. lugubris were not dissected and illustrated due to collection policies that do not allow detaching or dissecting parts of primary types; and the male terminalia of $O$. oxyptera were not dissected due to the fragile condition of the holotype. Non-type specimens of $O$. flavipleura, compared to the types, were dissected, analyzed and illustrated. For this, the abdomen was detached and treated according to the protocol of CuMming (1992) and afterwards stored in a plastic microvial containing glycerin. The wing, when necessary, was detached and mounted between cover slips in Canada balsam; the cover slips were glued to a cardboard. The vials with terminalia and wing mounts were attached to the pins of the respective specimens.

For label data of holotypes, individual lines are separated with a backslash ( $\backslash$ ), information on the back of the label is separated with two backslashes $(\backslash \backslash)$, and individual labels are separated with quotes (" "). All information is given exactly as written on the labels. Brackets ([ ]) indicate annotations that are not present on the specimen labels.

\section{TAXONOMY}

\section{Maerorichardia Hennig, 1937 \\ Figs. 1-8}

Maerorichardia Hennig, 1937: 31. References: Aczél, 1950: 22 (catalogue); Steyskal, 1968: 5 (catalogue); Hancock, 2010: 877 (key).

Type species: Maerorichardia lugubris Hennig (original designation).

Diagnosis and remarks. Maerorichardia is the only genus of Richardiidae with mid and hind tibiae thicker than their respective femora (Fig. 5), and the wing with the anal lobe distinctly developed (Fig. 8). Additionally, the only known species of Maerorichardia has the frons densely setulose, the lunule well developed, and the ocellar triangle slightly elongate, with the posterior ocelli not distinctly separated from the vertex (Figs. 3, 4), the proepimeral and katepisternal setae robust, the proepimeron and proepisternum bare, and the postmetacoxal bridge not completely sclerotized, the wing entirely microtrichose, and the oviscape distinctly long (Fig. 6), longer than tergites 3 and 4 together. The single described species is only known from the holotype.

Redescription. Body length $8.8 \mathrm{~mm}$; robust. Head (Figs. $3,4)$. Wider than high; wider than thorax. Eye oval, distinctly higher than wide. Vertex, in frontal view, straight. Ocellar triangle slightly elongate, inserted on apical third of frons, posterior ocelli not distinctly separated from vertex. Frons densely setulose; in lateral view, straight, not protruded; in frontal view, broad, lateral margins convergent anteriorly. Lunule distinctly developed. Antenna long; distance between antennae very small, less than half of diameter of scape. Scape and first flagellomere elongate. Parafacial slightly broad. Face high, oral margin slightly concave. Clypeus, in lateral view, not protruded; in frontal view, short, distinctly wider than high. Palpus developed and triangular. Gena short, smaller than one-sixth of eye height. Postcranium, in lateral view, distinctly broader on ventral two-thirds. Postgena short. Setae robust and long; subvibrissal setulae relatively developed and dense.

Thorax (Figs. 1, 2, 7). Scutum slightly longer than wide, densely and randomly setulose. Scutellum short and bare. Prosternum, proepimeron, metasternum and metapleuron nonsetulose. Katatergite non-setulose, densely pollinose. Metathoracic spiracle conspicuously setulose on posterior margin. Postmetacoxal bridge not completely sclerotized. Chaetotaxy: scapular seta absent; proepimeral, postpronotal and katepisternal setae robust; presutural supra-alar present; notopleural setae 2 ; postsutural supra-alar seta 1 ; postalar seta 1 ; intra-alar seta 1. Legs (Figs. 1, 5). Long and robust; fore femur distinctly thicker than fore tibia; mid and hind tibiae very swollen, distinctly thicker than respective femora, curved, dorsal margin convex. All femora with strong spine-like setae on antero- and posteroventral surfaces. Hind coxa bare on posterodorsal surface and without ventral projection. Wing (Fig. 8). Without spots; densely and entirely microtrichose. Veins bare. Vein $\mathrm{R}_{2+3}$ straight, without spurious vein. Vein $\mathrm{R}_{4+5}$ straight, then distinctly curved preapically toward vein $\mathrm{M}_{1}$. Vein $\mathrm{M}_{1}$ curved posteriorly to crossvein dm-cu. Crossvein $\mathrm{r}-\mathrm{m}$ inserted posterior to midlength of cell $\mathrm{dm}$. Vein $\mathrm{A}_{1}+\mathrm{CuA}_{2}$ long, reaching margin of wing, becoming weaker toward margin. Alula developed. Anal lobe distinctly developed.

Abdomen. Shiny, polished, without evident punctuation. Longer than thorax; oval, syntergite $1+2$ slightly narrower at base, and tergites 3-5 gradually narrower than apex of syntergite $1+2$. Syntergite $1+2$ with more than one preapical laterodorsal setae. Sternite 1 present, very reduced.

Female terminalia (Fig. 6). Oviscape very long, almost as long as combined length of tergites 1-5. Cerci apex rounded. Male terminalia. Unknown.

Included species and distribution. Maerorichardia lugubris Hennig (Bolivia: La Paz Department). 


\section{Maerorichardia lugubris Hennig, 1937}

Figs. 1-8

Maerorichardia lugubris Hennig, 1937: 31. Holotype female (SMTD). Type locality: Bolivia, La Paz Department, Mapiri. References: Aczél, 1950: 22 (catalogue); Steyskal, 1968: 5 (catalogue).

Diagnosis and remarks. The only known species is characterized by the body almost entirely dark brown, except the contrasting mid and hind tarsomeres and basal fourth of hind femur yellowish, body densely setulose, and wing brown, without spots, with alula, anal lobe, cells cua ${ }_{1}, \mathrm{~m}$, apical two-thirds of cell $r_{4+5}$ and apical third of cell $r_{2+3}$ paler brownish.

Description. Holotype female: Measurements (in $\mathrm{mm}$ ): body length 8.8 (not including oviscape); head 1.4; wing 7.0; abdomen 6.0 (including oviscape). Head (Figs. 3, 4). Head width-height ratio 1.44 . Frons-head ratio 0.43. Frons widthheight ratio 1.4. Face-clypeus ratio 0.34 . Ocelli-distance ratio 1.2. Entirely dark brown; frons, parafacial and ventral half of postcranium on border of eye densely silver pollinose. Setae and setulae black, except setulae on frons brown. Ocellar triangle slightly elongate, same color as frons, almost indistinguishable; ocelli whitish. Scape and base of pedicel pale brown; apex of pedicel, first flagellomere and arista dark brown. Scape three-fifths as long as pedicel. First flagellomere 3.0 times longer than high; base and apex similar in height. Ocellar seta long and strong, as long as orbital seta. Postocellar seta almost as long as ocellar seta. Genal and postgenal setae well developed. Postcranium densely covered with long black setulae. Palpus dark brown, triangular (scalene), apex distinctly wider than base. Prementum dark brown.

Thorax (Figs. 1, 2, 7). Entirely dark brown, whitish pollinose, denser on proepimeron, notopleuron, posterior third of anepisternum, anterior third of anepimeron and posterior half of katepisternum. Scutum and postpronotal lobe densely dark brown setulose. Intra-alar seta as long as postalar; postsutural dorsocentral setae 2, and scutellar seta 1. Legs (Figs. 1, 5). Robust and dark brown, except mid and hind tarsomeres and basal fourth of hind femur yellowish; densely black setulose. Mid coxa with two strong setae medially. All femora with strong antero- and posteroventral spine-like setae on apical half. Wing (Fig. 8). Brown, with alula, anal lobe, cells $\mathrm{cua}_{1}, \mathrm{~m}$, apical half of $r_{4+5}$ and apical third of $r_{2+3}$ paler brownish. Alula, anal lobe and cell $\mathrm{cu}_{\mathrm{p}}$ microtrichose. Costa distinctly arched proximal to costal break. Crossvein r-m exactly at apical third of cell $\mathrm{dm}$.

Abdomen. Entirely dark brown; non-pollinose, densely black setulose, except syntergite $1+2$ bare on median third. Syntergite $1+21.75$ times as long as tergite 3 ; with four preapical laterodorsal setae.

Female terminalia (Fig. 6). Oviscape $1.7 \mathrm{~mm}$ long. Not dissected.

Male. Unknown.

Holotype female, SMTD: "Bolivia - Mapiri [15²18.6'S, $\left.68^{\circ} 13^{\prime} \mathrm{W} ; 720 \mathrm{~m}\right] \backslash \mathrm{III} .03[1903] \backslash$ Sarampioni 700m [green label]" "Richardiidae $\backslash$ nov. gen. $\backslash \backslash$ Maerorichardia $\backslash$ lugubris [yellow label, handwritten]" "Staat. Museum für $\backslash$ Tierkunde Dresden $\backslash$ Coll. W. SCHNUSE, 1911 [white label from collection, subsequently added]" "HOLOTYPE [red label, subsequently added by the present authors]" "Holotype SMTD $\backslash$ Maerorichardia $\backslash$ lugubris Hennig, 1937, \Verified by Wendt 2014 [white label, subsequently added by the present authors]". The holotype is in excellent condition, no parts missing.

Distribution. Bolivia (La Paz).

\section{Odontomerella Hendel, 1912}

Figs. 9-38, 44-47

Odontomerella Hendel, 1912: 10. References: Aczél, 1950: 36 (catalogue); Steyskal, 1968: 7 (catalogue); Hancock, 2010: 876 (key).

Oxypterella Hennig, 1938: 116 (error).

Type species: Odontomerella oxyptera (original designation).

Diagnosis and remarks. Odontomerella species are small, not exceeding $5.8 \mathrm{~mm}$ in length. The compound eye is well developed, occupying most of the head, especially in lateral view, with the gena and postcranium very reduced (Figs. 17, 45). The face, in frontal view, is short, with the oral margin distinctly concave (Figs. 18, 23, 46). The first flagellomere is short, at most 1.8 times longer than high (Figs. 17, 24, 45). The mid femur lacks spine-like ventral setae, and crossvein $\mathrm{r}$ $\mathrm{m}$ is inserted proximal to the midlength of cell dm (Figs. 12, 47).

In the identification key provided by Hancock (2010), Odontomerella is presented in a dichotomy with Odontomera Macquart, 1843, sharing the occiput much narrower dorsally. However, in our analysis we noticed that the species of Odontomerella do not exhibit this character. The postcranium in Odontomerella is reduced and little wider ventrally (Figs. 17, 45), whereas in Odontomera it is developed, distinctly wider at basal two-thirds, especially medially (Fig. 39). Therefore, Odontomerella can be more easily differentiated from species of Odontomera by the combination of features listed above.

Within Richardiinae, there are nine genera with vein $\mathrm{A}_{1}+\mathrm{CuA}_{2}$ short, not reaching the wing margin: Antineuromyia Hendel, 1914 (in part), Johnrichardia Perez-Gelabert \& Thompson, 2006, Macrostenomyia Hendel, 1907, Odontomera, Oedematella Hendel, 1911, Sepsisoma Johnson, 1900, Oceanicia Enderlein, 1927, Odontomerella, and Ozaenina Enderlein, 1912. Perez-Gelabert \& Thompson (2006) suggested that the first six genera form a group characterized by having vein $\mathrm{A}_{1}+\mathrm{CuA}_{2}$ short, femora with apicoventral rows of spine-like setae, and postmetacoxal bridge completely sclerotized. However, these last two characters are shared with other genera that have an elongated vein $\mathrm{A}_{1}+\mathrm{CuA}_{2}$, reaching the wing margin, such as Hemixantha Loew, 1873, Beebeomyia Curran, 1934, Batrachophthalmum Hendel, 1911, Megalothoraca Hendel, 1911, and 


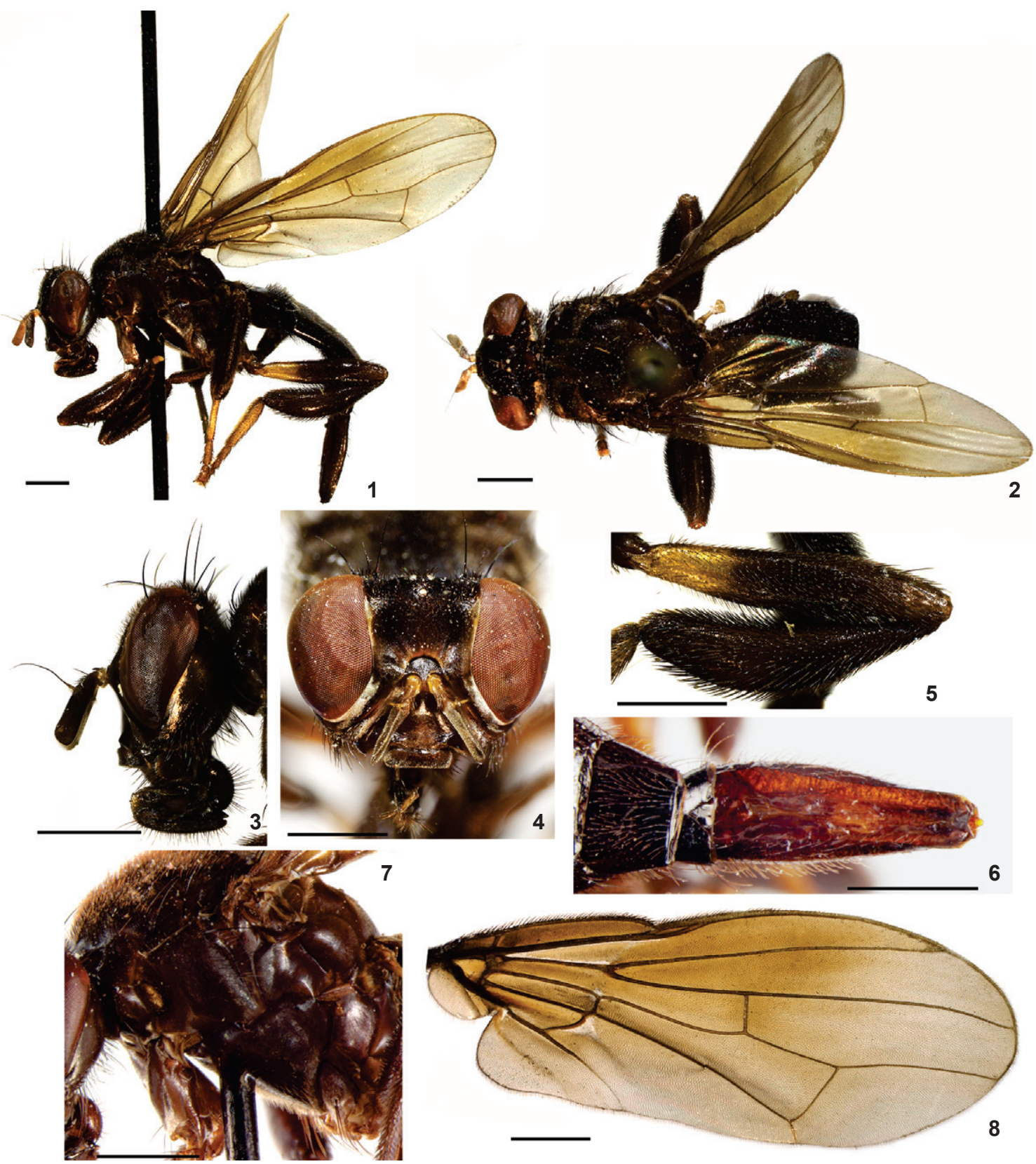

Figures 1-8. Maerorichardia lugubris Hendel, holotype female (SMTD): (1, 2) habitus: (1) lateral view; $(2)$ dorsal view; $(3,4)$ head: $(3)$ lateral view; (4) frontal view; (5) hind leg, anterior view; (6) oviscape, dorsal view; (7) thorax, lateral view; (8) left wing, dorsal view. Scale bars: $1.0 \mathrm{~mm}$.

Euolena Loew, 1873. Additionally, some genera that have vein $\mathrm{A}_{1}+\mathrm{CuA}_{2}$ short, do not have all femora with antero- and posteroventral spine-like setae, such as Odontomerella and Sepsisoma (in part). Therefore, the only exclusive character of the group proposed by Perez-Gelabert \& Thompson (2006), and the additional genera here included, is the short vein $\mathrm{A}_{1}+\mathrm{CuA}$.
However, preliminary results suggest that the short vein is an apomorphic condition within Richardiidae and that these genera form a monophyletic group (L.D. WENDT, unpub. data).

Redescription. Body length 4.5-5.8 mm; slender (Figs. 9, 20, 44). Head (Figs. 17-19, 23-25, 45, 46). Wider than high; wider than thorax. Eye slightly oval, slightly higher than wide; 

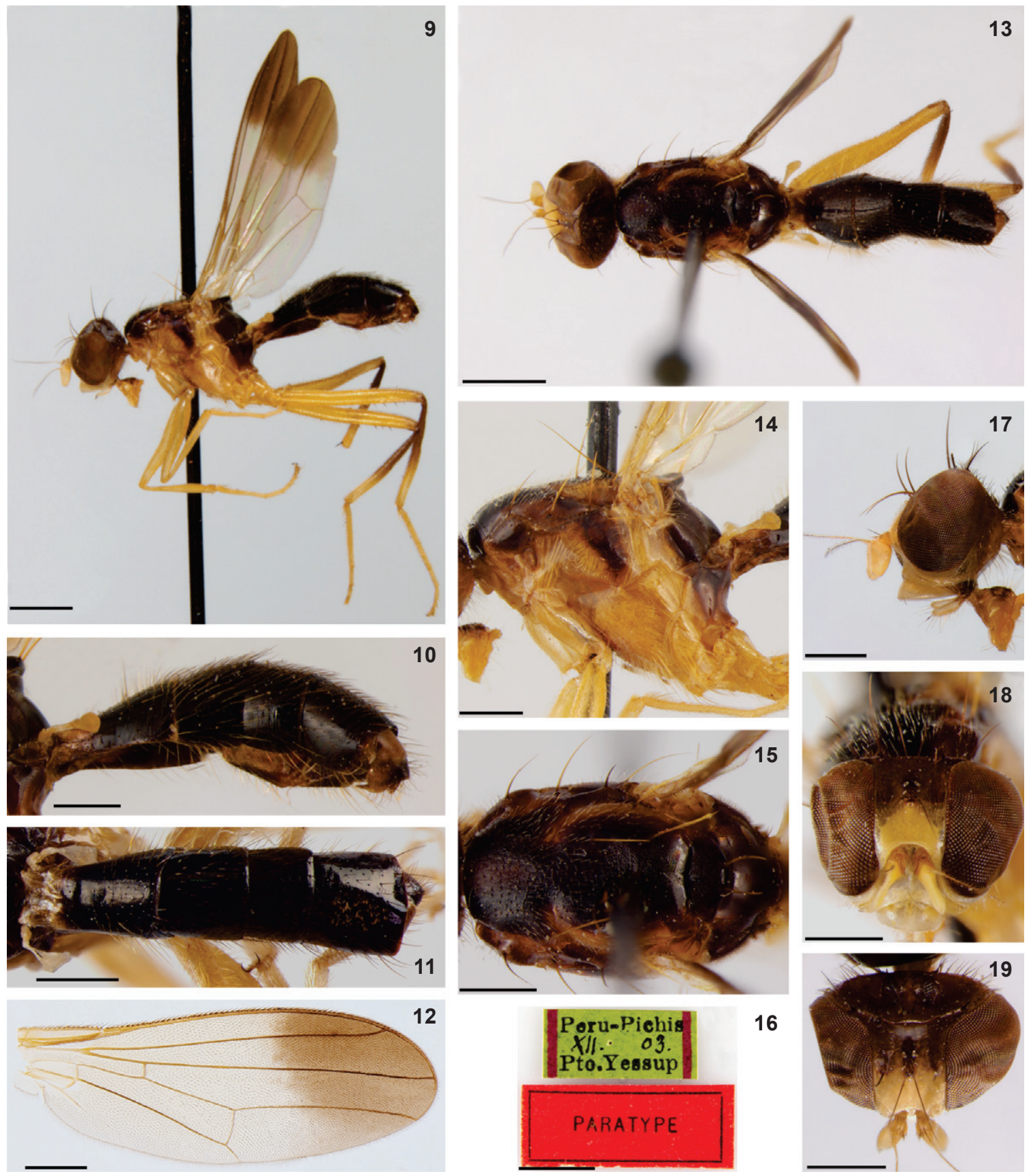

Figures 9-19. Odontomerella flavipleura (Hennig): $(9,10,13-19)$ paratype male (SMTD); $(11,12)$ non-type material; (9) habitus, lateral view; $(10,11)$ abdomen: (10) lateral view; (11) male (USNM), dorsal view; (12) female (MHNJP), left wing, dorsal view; (13) habitus, dorsal view; $(14,15)$ thorax: (14) lateral view; (15) dorsal view; (16) label; (17-19) head: (17) lateral view; (18) frontal view; (19) dorsal view. Scale bars: $9,13=1.0 \mathrm{~mm}, 10-12,14-15,17-19=0.5 \mathrm{~mm}, 16=5.0 \mathrm{~mm}$.

well developed, occupying most of head. Vertex, in frontal view, straight. Ocellar triangle elongate, on medial third of frons; posterior ocelli distinctly displaced from vertex. Frons sparsely setulose; in lateral view straight, not protruded anteriorly; in frontal view relatively narrow, lateral margins parallel. Lunule slightly or distinctly developed. Antenna short; distance be- 


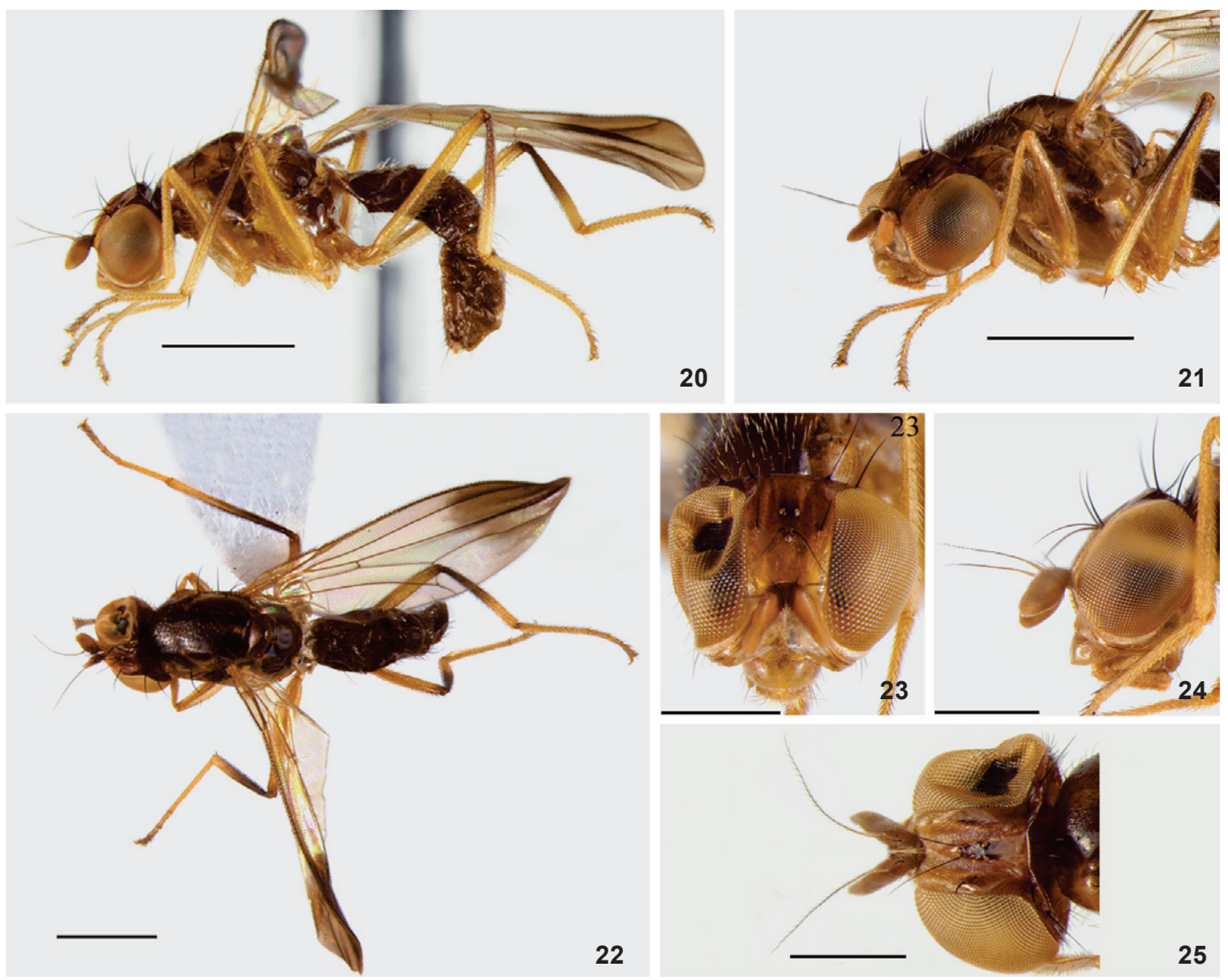

Figures 20-25. Odontomerella flavipleura (Hennig), non-type female (MHNJP): (20) habitus, lateral view; (21) head and thorax, laterofrontal view; (22) habitus, dorsal view; (23-25) head: (23) frontal view; (24) lateral view; (25) dorsal view. Scale bars: 20-22 = 1.0 mm, 23-25 = $0.5 \mathrm{~mm}$.

tween antennae very small, less than diameter of scape. First flagellomere short, at most 1.8 times longer than high. Parafacial narrow. Face short, oral margin distinctly concave. Clypeus, in lateral view, not protruded; in frontal view, developed and high, almost as wide as high. Palpus elongate, linear or subspatulate. Gena very short, smaller than one-tenth of eye height. Postcranium, in lateral view, narrow, slightly broader medially and ventrally. Postgena short. Setae robust and long, including ocellar and postocellar setae; subvibrissal setulae weak and sparse.

Thorax (Figs. 14, 15, 22, 44). Scutum elongate, distinctly longer than wide; densely and randomly setulose. Scutellum short and bare. Prosternum, proepimeron, metasternum and metapleuron setulose. Katatergite non-setulose, densely pollinose. Metathoracic spiracle weakly setulose on posterior margin. Postmetacoxal bridge completely sclerotized. Chaetotaxy (based on O. flavipleura and part of O. oxyptera): scapular and presutural supra-alar setae absent; postpronotal seta present; proepimeral and katepisternal setae weak; notopleural setae 2; postsutural supra-alar seta 1 ; postalar and intra-alar setae very reduced in $O$. flavipleura (not examined, area damaged, in O. oxyptera). Legs (Figs. 9, 20, 44). Elongate and slender. Femora slightly thicker than tibiae; tibiae thin and straight. Fore femur with or without spine-like ventral setae. Mid femur without spine-like setae; thicker on basal two-thirds. Hind femur with robust or weak spine-like setae on antero- and posteroventral surfaces. Hind coxa bare on posterodorsal surface and without ventral projections. Wing (Figs. 12,47). Slightly brownish or yellowish with conspicuous spot on apical third; densely microtrichose. Veins microtrichose. Vein $\mathrm{R}_{2+3}$ straight, without spurious vein. Vein $R_{4+5}$ straight, very slightly curved preapically toward vein $M_{1}$. Vein $\mathrm{M}_{1}$ arched posterior to crossvein dm-cu. Crossvein $\mathrm{r}-\mathrm{m}$ inserted proximal to midlength of cell $\mathrm{dm}$. Vein $\mathrm{A}_{1}+\mathrm{CuA} \mathrm{A}_{2}$ short, not reaching wing margin. Alula and anal lobe normally developed. 
Abdomen (Figs. 10, 11). Metallic, without conspicuous punctation. Longer than thorax; oblong, syntergite $1+2$ with more than one preapical laterodorsal setae, slightly narrower at base; and tergites 3-5 similar in width or male of O. flavipleura with tergite 5 gradually widened. Sternite 1 absent.

Female terminalia. Based on O. flavipleura (Figs. 26-30): Oviscape elongate, densely setose; straight at apex, without apical and medial cuticular extension. Taenia short and slightly sclerotized. Eversible membrane long and weakly sclerotized. Sternite and tergite 8 not fused and similar in length. Two spherical and strongly sclerotized spermathecae.

Male terminalia. Based on O. flavipleura (Figs. 31, 32, 37, 38): Reduced. One robust and curved prensiseta inserted preapically on medial surstylus.

Included species and distribution. Odontomerella oxyptera (Brazil, Amazon River) and O. flavipleura (Hennig), new combination (Peru, Bolivia).

\section{Odontomerella flavipleura (Hennig, 1938), new combination}

Figs. 9-38

Odontomera flavipleura Hennig, 1938: 115. Holotype male, two males and one female paratypes, SMTD. Type locality: Bolivia, Mapiri, Sarampiuni. References: Aczél, 1950: 34 (catalogue); Steyskal, 1968: 7 (catalogue).

Diagnosis and remarks. The new combination is justified because this species has numerous features in common with Odontomerella oxyptera, as listed above. Species of Odontomera are recognized principally by having the postcranium, in lateral view, narrow dorsally, much narrower on the dorsal third than on the ventral two-thirds (Fig. 39), all femora with robust spine-like setae (Perez-Gelabert \& Thompson 2006), crossvein r-m at midlength of cell dm (Fig. 40) (HENDeL 1911, Steyskal 1958), the abdomen petiolate (Hancock 2010), the katatergite setulose, female with tip of cerci pointed (Fig. 43) and oviscape with apical cuticular extension (Fig. 42), and male with prensiseta inserted apically (Fig. 41) (L.D. WENDT, unpub. data).

Odontomerella flavipleura is distinguished from O. oxyptera by the following characters: lunule slightly developed; palpus yellow, linear and rounded at apex; scutum and scutellum dark brown almost black, or brown, except lateral region posterior to transverse suture brown or pale brown; postpronotal lobe, notopleuron, and posterior half of anepisternum brown; proepisternum, proepimeron, anterior half of anepisternum, katepisternum, anepisternum and anterior half of meron yellow; fore femur without spine-like ventral setae, with one or two long black preapical setae on posteroventral surface.

Redescription. Male paratypes: Measurements (in mm; $\mathrm{n}=2$ ): body length 5.1-5.4; head 0.89-0.93; abdomen 2.502.70; wing 4.02-4.21. Head (Figs. 17-19). Head width-height ratio 1.37-1.40. Frons-head ratio $0.34-0.38$. Frons width-height ratio $0.80-0.82$. Face-clypeus ratio 1.10-1.20. Ocelli-distance ratio 2.60-2.80. Lunule slightly developed, yellow. Frons brown on dorsal half and yellow on ventral half. Postcranium brown. Ocellar triangle brown; ocelli yellowish. Parafacial, gena, face and clypeus yellowish. Parafacial and dorsal half of gena densely whitish pollinose. Antenna entirely pale brown, or scape and pedicel yellowish orange, first flagellomere yellowish, arista brown. Scape very short, onefourth as long as pedicel. First flagellomere 1.8 times longer than high. Arista with dense short pubescence. Ocellar, vertical and orbital setae brownish orange. Ocellar seta longer than orbital seta. Inner vertical seta longer than outer vertical seta. Genal and postgenal setae weak and yellow. Postcranium densely yellowish setulose. Palpus yellow; linear, apex and base similar in width, apex rounded. Prementum yellow or brown, and labella yellowish orange.

Thorax (Figs. 14, 15). Scutum and scutellum dark brown, except lateral region posterior to transverse suture, brown. Scutum densely yellowish setulose. Postpronotal lobe, notopleuron, and posterior half of anepisternum brown. Proepisternum, proepimeron, anterior half of anepisternum, katepisternum, anepisternum and anterior half of meron yellow. Posterior half of meron, katatergite, anatergite and mediotergite brown or dark brown. Postmetacoxal bridge brown or pale brown. Postpronotal lobe sparsely yellowish setulose. Postpronotal seta long, black, almost as long as anterior notopleural seta. Proepimeral seta weak. Setae of scutum, scutellum and mesopleuron yellow or pale brown. Dorsocentral setae 2, very long, anterior slightly shorter and thinner than posterior seta; posterior dorsocentral seta and scutellar seta similar in length. Postalar and intra-alar setae very short, almost indistinct from setulae around them. Scutellar seta 1. Legs (Fig. 9). Slender; yellow, except mid and hind tibiae on basal half or third pale brown. Fore femur without spine-like ventral setae; with preapical posteroventral row of long black or brownish setae. Hind femur with weak spine-like setae on apical third or apical fourth of anteroventral surface. Wing (Fig. 12, photo of female non-type material). Yellowish, with large brown spot on apical third. Entirely microtrichose, except cells bm and $\mathrm{cu}_{\mathrm{p}}$, and alula. Vein $\mathrm{r}-\mathrm{m}$ inserted at basal two-fifths of cell $\mathrm{dm}$. Vein $\mathrm{M}_{1}$ slightly arched posterior to crossvein $\mathrm{dm}$-cu.

Abdomen (Fig. 10, photo of paratype male; Fig. 11, photo of male non-type material). Metallic dark blue, except sub-base of syntergite $1+2$ yellow. Tergites non-pollinose; long and brownish setulose. Syntergite 1+2 1.3 times longer than tergite 3 ; with three brownish laterodorsal preapical setae. Tergites 3 and 5 similar in length, slightly longer than tergite 4; tergites 3 and 4 as wide as apex of syntergite $1+2$, tergite 5 gradually wider posteriorly. Description and illustrations of sternites based on non-type material compared with paratypes: Sternites without anterior apodemes; brown. Sternite 1 absent. Sternite 2 elongate, 4.0 times longer than wide. Sternites 3 (Fig. 

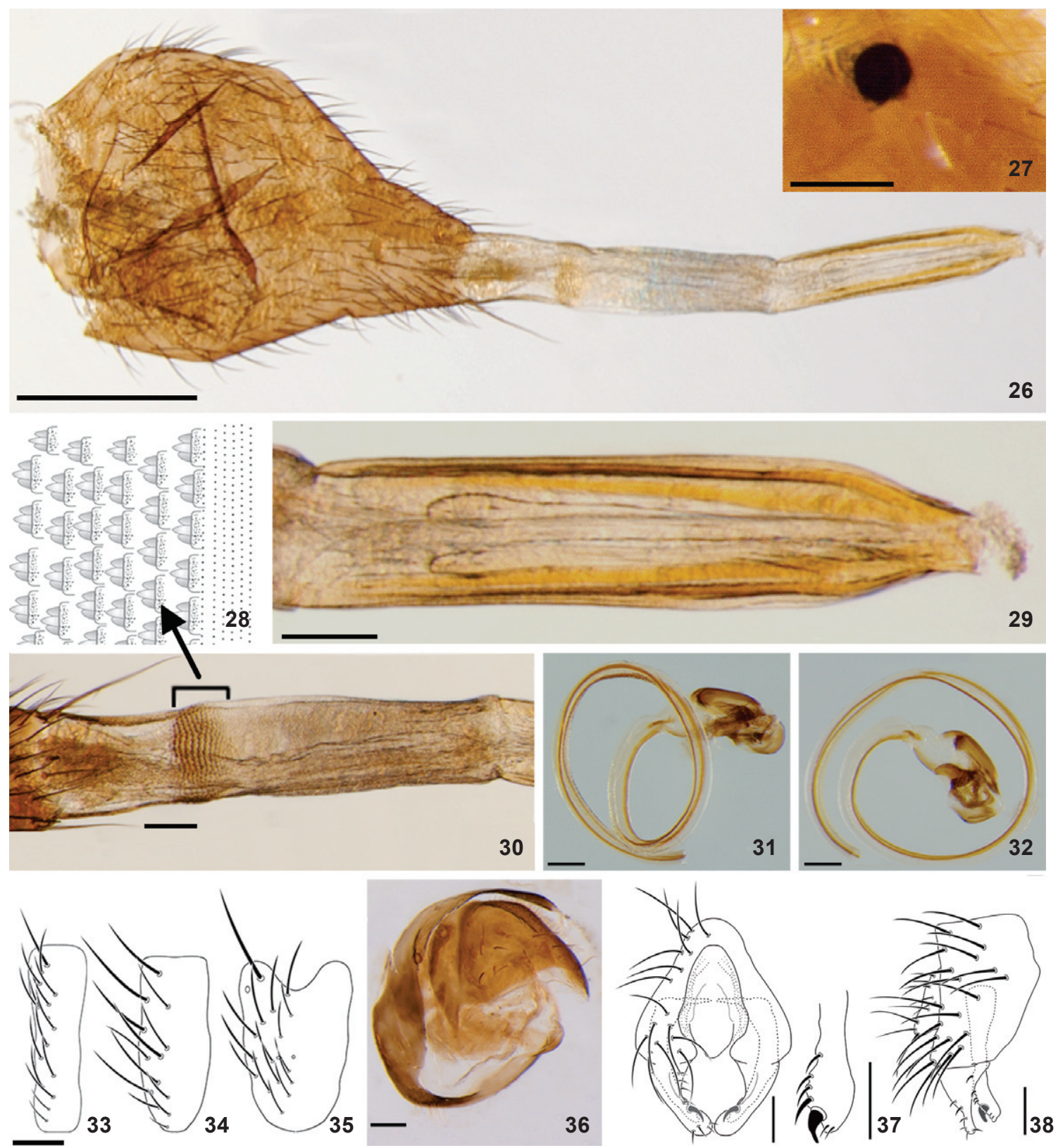

Figures 26-38. Odontomerella flavipleura (Hennig), non-type material: (26-30) female (MHNJP): (26) terminalia, general dorsal view, oviscape, taenia, eversible membrane and segment 8; (27) spermatheca; (28) drawing of denticles of eversible membrane, in detail; (29) segment 8, dorsal view; (30) eversible membrane, in detail, dorsal view; (31-39) male (MHNJP): (31, 32) distiphallus; (33) sternite 3; (34) sternite 4; (35) sternite 5; (36) tergite 6 and sternite 6, syntergosternite 7+8, spiracles 6 and 7, lateroposterior view; (37, 38) drawing of epandrium, lateral and medial surstyli, and cerci: (37) left side: posterior view (setulae on cerci were not represented); right side: apex of medial surstylus, in detail; (38) lateral view. Scale bars: $26=0.5 \mathrm{~mm}, 27-38=0.1 \mathrm{~mm}$.

33) and 4 (Fig. 34) densely setulose, rectangular and elongate, 3.1 and 2.4 times longer than wide, respectively. Sternite 5 heart-shaped, 1.51 times longer than wide (Fig. 35). Sternite 6 present, slightly sclerotized, reduced to small plate; with vesti- gial spiracle. Tergite 6 with thin yellow setae of similar length, on ventral third; with conspicuous spiracle. Syntergosternite $7+8$ brownish, with sparse setae on apical half; with conspicuous spiracle (Fig. 36). 


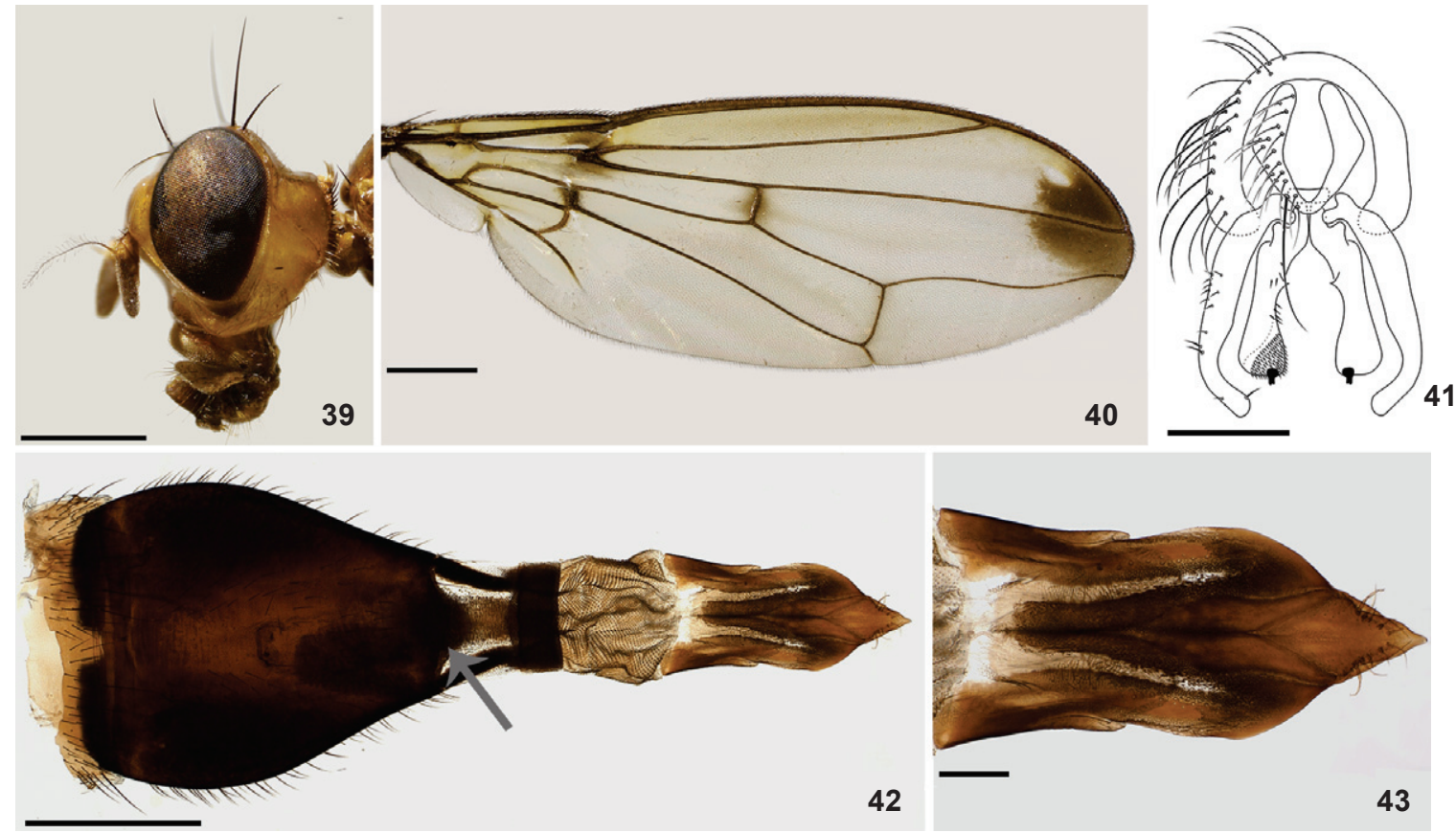

Figures 39-43. Odontomera sp. near Odontomera ferruginea Macquart, non-type material (LACM): (39-41) male: (39) head, lateral view; (40) left wing, dorsal view; (41) drawing of epandrium, lateral and medial surstyli, and cerci, posterior view; $(42,43)$ female, terminalia: (42) general dorsal view, oviscape, taenia, eversible membrane, segment 8 and cerci (grey arrow indicates the apical cuticular extension); (43) segment 8 and cerci, in detail, dorsal view. Scale bars: 39, 40, $42=1.0 \mathrm{~mm}, 41,43=0.2 \mathrm{~mm}$.

Male terminalia (Figs. 31, 32, 37, 38). Description and illustrations based on non-type material compared with paratypes. Reduced. Apex of epandrium and base of lateral surstylus almost entirely fused. Epandrium densely ciliated. Lateral surstylus distinctly wider on basal half, rounded at apex; setulose (Figs. 37, 38). Medial surstylus slightly wider on apical third; with relatively long setulae on apical third of posterior margin, each setula inserted on slightly produced and rounded area (Fig. 37); rounded at apex, two setulae at apex (Fig. 37). Prensiseta robust, inserted preapically, curved and pointed (Figs. 37, 38). Distiphallus very long; non-setulose and without modified setae; with plates at apex strongly sclerotized (Figs. 31, 32).

Variation, male non-type material. Measurements: 4.6 body length, 2.3 abdomen. First flagellomere yellow. Posterior notopleural seta black.

Female, non-type material (Figs. 20-30). Similar to male, except: Head (Figs. 23-25). Parafacial, gena, face and clypeus brownish. First flagellomere pale brown. Thorax (Figs. 20-22). Scutum and scutellum brown, except lateral region posterior to transverse suture pale brown. Anterior and posterior notopleural setae, anterior dorsocentral seta and postsutural supra-alar seta black. Legs (Fig. 20). Fore femur with only one long black preapical seta on posteroventral surface. Abdomen. Dark brown, except sub-base of syntergite 1+2 yellow. Female terminalia (Figs. 26-30). Oviscape pale brown, $1.2 \mathrm{~mm}$ long, distinctly wider on basal two-thirds, abruptly narrowed on apical third. Taenia weakly sclerotized, distinctly less sclerotized than oviscape; short, one-fourth as long as oviscape (Fig. 26). Eversible membrane narrow and long, two-thirds as long as oviscape; weakly sclerotized; with short submedial set (Figs. 26,30 ) of robust and aligned denticles, tri- or tetralobate (Fig. 28). Tergite and sternite 8 narrow, not fused to each other, similar in length (Fig. 29). Apex of cerci rounded (the cerci were damaged during dissection, so that it was not possible to observe and illustrate these structures in detail; the rounded shape of the apex was observed and described before the dissection). Two spherical and strongly sclerotized spermathecae (Fig. 27, only one illustrated), similar in size.

Observed material: Paratypes, SMTD. Peru, Pichis, xii.1903, Pto Yessup [= Pasco: Río Pichis, Yesup, $10^{\circ} 38^{\prime} \mathrm{S}$ $75^{\circ} 11^{\prime} \mathrm{W}$ ] (1 male); Meshagua [= Ucayali, Mishagua, $11^{\circ} 12^{\prime} 17^{\prime \prime} \mathrm{S}$ 7259'32"W], 26.ix.1903, Urubamba River (1 male).

Additional material. Peru, Cusco, Estación Biologica Villa Carmen, $12^{\circ} 54^{\prime} 09^{\prime \prime S} 71^{\circ} 41^{\prime} 97^{\prime \prime} \mathrm{W}, 702$ m, 27.xi.2012-20.i.2013, A.L. Norrbom, E. Rodriguez, G.J. Steck and B.D. Sutton cols. (1 female, MHNJP); same locality, $12^{\circ} 58^{\prime} 97^{\prime \prime} \mathrm{S} 71^{\circ} 41^{\prime} 97^{\prime \prime} \mathrm{W}, 577 \mathrm{~m}$, 7.iv.2014, M. Choque col. (1 male, USNM).

Distribution. Bolivia (La Paz), Peru (Cusco, Pasco, Ucayali). 


\section{Odontomerella oxyptera Hendel, 1912}

Figs. $44-47$

Odontomerella oxyptera Hendel, 1912: 11. Holotype male (BMNH). Type locality: Brazil, Amazonas River (Amazonas or Pará State). References: Hennig, 1938: 116 (citation); Aczél, 1950: 36 (catalogue); Steyskal, 1968: 7 (catalogue).

Diagnosis and remarks. Both species of Odontomerella have the thorax partially dark brown, and the abdomen dark blue, the legs yellow, and the wing with a conspicuous brown spot at the apex. But O. oxyptera is easily differentiated from $O$. flavipleura by having a mostly dark brown thorax, except postpronotal lobe pale brown, face and clypeus dark brown, palpus subspatulate, and fore femur with antero- and posteroventral robust spine-like setae.

Redescription. Holotype male: Measurements (in $\mathrm{mm}$ ): body length 5.8; head 0.9; abdomen 2.7; wing 4.5. Head (Figs. $45,46)$. Head width-height ratio 1.46. Frons-head ratio 0.33 . Frons width-height ratio 1.20. Face-clypeus ratio 0.77. Ocellidistance ratio 2.00. Lunule distinctly developed. Frons, lunule and postcranium pale brown. Ocellar triangle black; ocelli whitish. Parafacial and gena yellow, densely whitish pollinose. Face and clypeus dark brown. Scape, pedicel and arista brown. Scape short, one-third as long as pedicel. First flagellomere brownish yellow; short, 1.5 times longer than high. Arista long and densely pubescent. Setae black. Ocellar seta longer than orbital seta. Inner vertical seta slightly longer than outer vertical seta. Genal and postgenal setae weak and black. Postcranium densely whitish and brownish setulose. Palpus dark brown, with base yellow; subspatulate, apex distinctly wider than base. Prementum yellow, labella dark brown.

Thorax (Fig. 44). Dark brown, except postpronotal lobe pale brown. Scutum densely whitish setulose. Postpronotal lobe sparsely setulose. Posterior half of thorax badly damaged, impairing observation of structures and chaetotaxy (Fig. 44). Legs (Fig. 44). Slender and entirely yellow; densely yellowish setulose. Fore femur with two robust preapical spine-like setae on antero- and posteroventral surfaces. Hind femur with anteroand posteroventral rows of robust spine-like setae on apical two-thirds. Wing (Fig. 47). Slightly brownish, with large brown spot on apical third. Entirely microtrichose, except cells bm and $\mathrm{cu}_{\mathrm{p}}$, and alula. Crossvein $\mathrm{r}-\mathrm{m}$ inserted at basal third of cell $\mathrm{dm}$. Vein $\mathrm{M}_{1}$ strongly arched posteriorly to crossvein $\mathrm{dm}-\mathrm{cu}$.

Abdomen. Entirely metallic dark blue. Tergites non-pollinose; with black long setulae. Syntergite 1+2 1.4 times longer than tergite 3 , with three black laterodorsal preapical setae. Tergites 3-5 as wide as apex of syntergite $1+2$; tergite 3 slightly longer than tergite 4 ; tergites 4 and 5 similar in length.

Male terminalia. Not observed.

Female. Unknown.

Holotype male, BMNH: "Odontomerella \det. F. Hendel $\backslash$ oxyptera, \Hendel" "R. Amazonas $\backslash$ Brasil $\backslash$ H.W. Bates $\backslash 66.53$ [label handwritten]" "Amazon. $\backslash 66.53$ " "Holo $\backslash$ type [white and
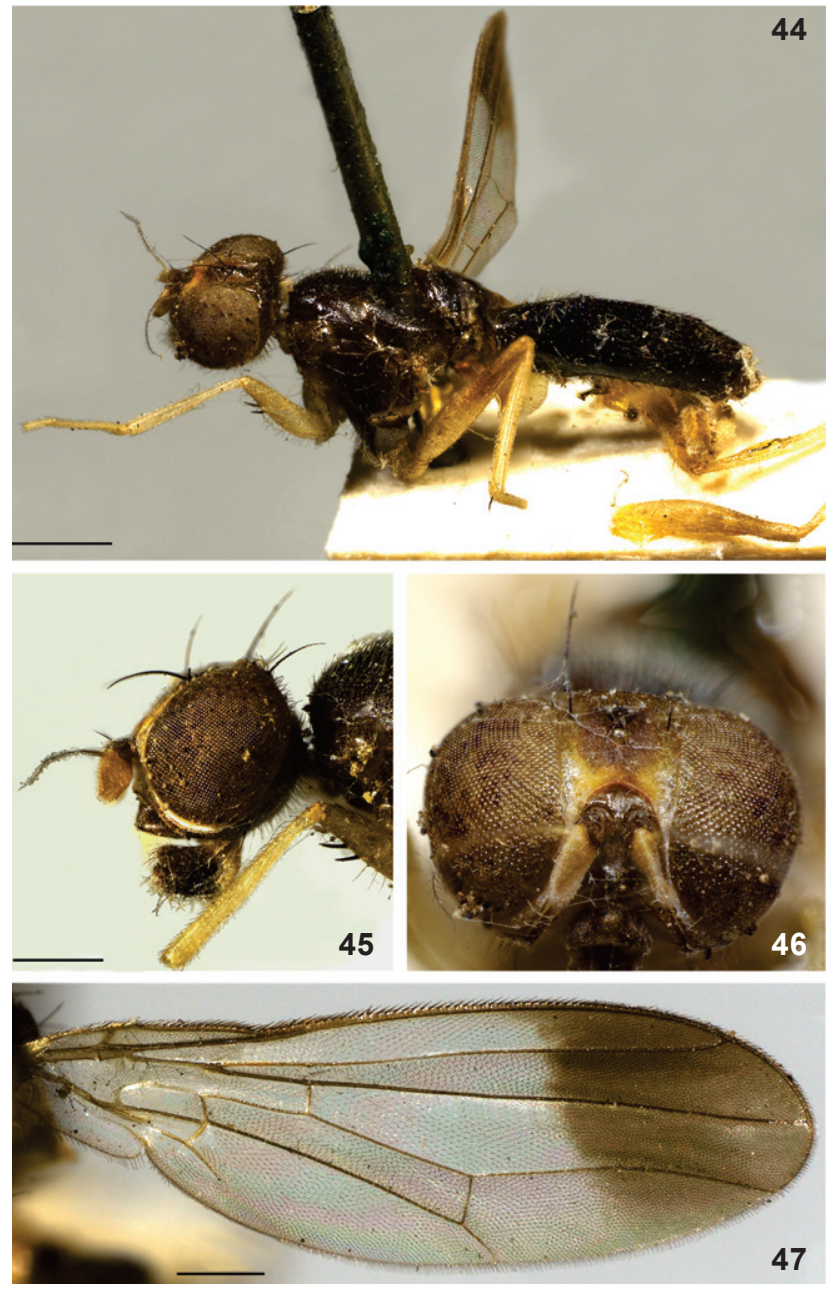

Figures 44-47. Odontomerella oxyptera Hendel, holotype male (BMNH): (44) habitus, lateral; $(45,46)$ head: (45) lateral view; (46) frontal view; (47) right wing. Scale bars: $44=1.0 \mathrm{~mm}, 45$, $47=0.5 \mathrm{~mm}$.

red circular label]" "HOLOTYPE $\backslash$ Odontomerella $\backslash$ oxyptera $\backslash$ Hendel $\backslash$ verified by $\backslash$.E. Chainey, 2002" "BMNH(E)\#\251412". The collector, Henry Walter Bates, spent 11 years (1848-1859) exploring the rainforests of the Brazilian Amazon (Pará and Amazonas States). However, it was not possible to determine the specific locality and date of collecting of the holotype. The specimen is in bad condition: the posterior part of the thorax (including the scutum, scutellum, subscutellum and mediotergite) was damaged by the pin preventing observation of some sclerites and part of the chaetotaxy. The left wing is missing. The mid and hind legs are glued onto a card below the specimen.

Distribution. Brazil (Amazon River: State of Amazonas or Pará). 


\section{ACKNOWLEDGEMENTS}

This research was funded by Conselho Nacional de Desenvolvimento Científico e Tecnológico (CNPq) through the support of the project "Ampliação do conhecimento em taxonomia, sistemática e aspectos biológicos de Tephritoidea (Diptera) na Região Neotropical, em especial das famílias Tephritidae e Richardiidae" (process 400829/2014-2) and by Fundação de Amparo à Pesquisa do Estado do Amazonas (FAPEAM) and Coordenação de Aperfeiçoamento de Pessoal de Nível Superior (CAPES) through the support of the project "Incremento do conhecimento da diversidade, formação e fixação de especialistas em Sistemática de Diptera (Insecta) na Amazônia". We are grateful to K. Goodger (BMNH), U. Kallweit (SMTD) and A.L. Norrbom (USNM) for lending specimens. LD Wendt thanks CNPq for the fellowship provided (process $163567 / 2014-0)$, she also thanks Dr. Uwe Kallweit for welcoming her at the SMTD and Dr. Allen L. Norrbom at the USNM; these visits were funded by the German Academic Exchange Service (DAAD) and by CAPES/FAPEAM, respectively. The typespecies photos were taken with Automontage equipment available to us through the projects "Amazonas: Diversidade de insetos ao longo de suas fronteiras" (PRONEX/FAPEAM process 1437/2007/NTO318/07) headed by Dr. José Albertino Rafael from Instituto Nacional de Pesquisas da Amazônia and the "Taxonline: Rede Paranaense de Coleções" headed by Dr. Luciane Marinoni from Universidade Federal do Paraná.

\section{LITERATURE CITED}

AczéL M (1950) Catalogo de la sufamilia americana "Richardiinae" (Dipt. Acalypt. Otitidae). Acta Zoologica Lilloana 9: 5-47.

Alencar B de A, Wendt LD, Ale-Rocha R (2013) Richardia Robineau-Desvoidy (Diptera, Tephritoidea, Richardiidae) from Central Amazon, Brazil. Revista Brasileira de Entomologia 57(2): 202-208. doi: 10.1590/S008556262013005000015

Carvalho CJB DE, WolfF M, Wendt LD (2011) A new stalk-eyed species of Batrachophthalmum Hendel (Diptera, Richardiidae) from Colombia. Zootaxa 2932: 41-46.

Cumming JM (1992) Lactic acid as an agent for macerating Diptera specimens. Fly Times 8: 7.

Cumming JM, Wood DM (2009) Morphology and terminology, p. 9-50. In: Brown BV, Borkent A, Cumming JM, Wood DM, Woodley NE, Zumbado MA (Eds.). Manual of Central American Diptera. Ottawa, NRC Research Press, vol. 1.

Hancock EG (2010) Family Richardiidae (Richardiid flies), p.
871-879. In: Brown BV, Borkent A, Cumming JM, Wood DM, Woodley NE, Zumbado MA (Eds.). Manual of Central American Diptera. Ottawa, NRC Research Press, vol. 2

Hendel F (1911) Diptera. Fam. Muscaridae, Subfam. Richardiinae. Genera Insectorum 113: 1-56.

Hendel F (1912) Neue Muscidae acalyptratae. Wiener Entomologische Zeitung 31: 1-20.

HenNig W (1937) Beiträge zur Systematik der Richardiiden (Dipt.). Revista de Entomologia 7: 21-34, 306-312, 484486.

HeNnIG W (1938) Beiträge zur Kenntnis der Richardiiden (Dipt.). Revista de Entomologia 8: 111-122.

Norrbom AL, Kim KC (1988) Revision of the schausi group of Anastrepha Schiner (Diptera: Tephritidae), with a discussion of the terminology of the female terminalia in the Tephritoidea. Annals of the Entomological Society of America 81: 164-173.

Perez-Gelabert DE, Thompson FC (2006) A new genus and species of Richardiidae (Diptera) from Hispaniola. Zootaxa 1259: 25-31.

Steyskal GC (1958) Notes on the Richardiidae, with a review of the species known to occur in the United States (Diptera, Acalyptratae). Annals of the Entomological Society of America 51: 302-310.

Steyskal GC (1968) Famly Richardiidae, p. 1-20. In: Papavero N (Ed.). A catalogue of the Diptera of the Americas South of the United States. São Paulo, Departamento de Zoologia, Secretaria da Agricultura, Brasil.

Wendt LD, Ale-Rocha R (2012) Redescription of the genus Coniceps Loew, 1873 (Diptera, Richardiidae). Zootaxa 3238: 49-56.

Wendt LD, Ale-Rocha R (2014a) Taxonomic notes of Hemixantha Loew (Diptera, Richardiidae) with description of a new species from Amazon Region. Zoologia 31: 88-96. doi: 10.1590/S1984-46702014000100010

Wendt LD, Ale-Rocha R (2014b) Taxonomic revision of wasplike richardiids, Neoidiotypa Osten-Sacken (Diptera, Tephritoidea, Richardiidae). Zootaxa 3857: 527-550. doi: 10.11646/zootaxa.3857.4.4

Wendt LD, Ale-Rocha R (2015) Antlered richardiid flies: new species of Richardia (Tephritoidea, Richardiidae) with antlerlike genal processes. Entomological Science 18: 153-166. doi: 10.1111/ens.12122

White IM, Norrbom AL, Headrick, DH, Carroll LE (1999) Glossary, p. 881-924. In: Aluja M, Norrbom AL (Eds.). Fruit flies (Tephritidae): Phylogeny and evolution of behavior. Boca Raton, CRC Press.

Submitted: 19 May 2015

Received in revised form: 29 June 2015

Accepted: 13 July 2015

Editorial responsibility: Gabriel L.F. Mejdalani

ZOOLOGIA 32 (4): 306-316, August 2015 